\title{
PENERAPAN MODEL PEMBELAJARAN KOOPERATIF TIPE TEAMS GAMES TOURNAMENT (TGT) DALAM MENINGKATKAN HASIL BELAJAR IPS SISWA KELAS IV SEKOLAH DASAR
}

\author{
Rosikhatul Ilmiyah, Sri Utaminingsih, Ika Oktavianti \\ Program Studi Pendidikan Guru Sekolah Dasar \\ Fakultas Keguruan dan Ilmu Pendidikan \\ Universitas Muria Kudus
}

\begin{abstract}
Class action research was success to improving the student's achievement, student's activities, and teaching management with Teams Games Tournament (TGT) type of Cooperative Learning Model. Classical completeness of student's achievement pre-cycle is $52.7 \%$ with the average 61.4, in cycle I increase become $69.4 \%$ with the average 71.48, and in cycle II increase become $75 \%$ with the average 73.9. In cycle I, the students in teaching-learning activity got the average score 2.46 with good enough criterion, in cycle II increase become 2.87 with good criterion. In cycle I, the teaching management of the teacher got the average score 2.36 with good criterion, in cycle II increase become 3.08 with excellent criterion.
\end{abstract}

\begin{abstract}
ABSTRAK
Telah berhasil dilakukan penelitian tindakan kelas menggunakan model pembelajaran kooperatif tipe Teams Games Tournament TGT menunjukkan peningkatan hasil belajar, aktivitas siswa, dan pengelolaan pembelajaran guru. Ketuntasan klasikal siswa pra siklus sebesar 52,7\% dengan rata-rata 61,4, meningkat pada siklus I menjadi 69,4\% dengan rata-rata 71,48, dan pada siklus II meningkat menjadi $75 \%$ dengan rata-rata 73,9. Aktivitas belajar siswa siklus I memperoleh skor rata-rata 2,46 dengan kriteria cukup baik, meningkat pada siklus II menjadi 2,87 dengan kriteria baik. Pengelolaan pembelajaran guru siklus I memperoleh skor ratarata 2,36 dengan kriteria baik, meningkat pada siklus II menjadi 3,08 dengan kriteria sangat baik.
\end{abstract}

Kata Kunci: Hasil Belajar IPS, PTK, Teams Games Tournament (TGT).

\section{PENDAHULUAN}

IPS merupakan salah satu mata pelajaran yang wajib diajarkan di SD. Mata pelajaran IPS merupakan sebuah nama mata pelajaran integrasi dari cabang ilmu-ilmu sosial seperti sejarah, geografi, dan ekonomi serta cabang ilmu sosial lainnya. Suprayogi (2011:

mengemukakan bahwa tujuan IPS adalah menghasilkan warganegara yang efektif, anggota masyarakat yang mampu berpikir, bersikap dan bertindak sesuai dengan keadaan masyarakat yang dinamis. Untuk mencapai tujuan tersebut, sekolah malalui 
studi sosial perlu membekali subjek didik dengan berbagai kemampuan, yakni kemampuan penguasaan terhadap dimensi pengetahuan (knowledge), keterampilanketerampilan (skills), nilai dan sikap (values and attitudes), dan partisipasi sosial (social participation).

Hasil belajar IPS di SDN 1 Kedungsarimulyo masih rendah yaitu dibawah KKM (<63). Pada ulangan harian IPS semester 1 tahun pelajaran 2013/2014 dari 36 siswa, jumlah siswa yang mendapat nilai 63 ke atas atau tuntas belajar 19 siswa $(52,7 \%)$, nilai terendah 30, nilai tertinggi 90 , dan nilai rata-rata 61,4 disebabkan karena materi IPS di kelas IV dianggap terlalu banyak, dan tidak menarik sehingga siswa tidak mempunyai motivasi yang kuat untuk belajar. Hal tersebut dapat dilihat ketika pembelajaran IPS berlangsung, ada siswa yang berbicara dengan temannya, ada siswa yang asyik bermain, bahkan ada yang mengantuk. Sebagian besar siswa kelas IV tidak tertarik dan menganggap IPS sebagai mata pelajaran yang membosankan.

Berkaitan dengan hasil observasi awal, peneliti berdiskusi dengan guru kelas KAJIAN TEORI

MODEL PEMBELAJARAN KOPERATIF TIPE TEAMS GAMES TOURNAMENT (TGT)

Pembelajaran merupakan suatu proses yang terdiri dari kombinasi dua untuk menentukan pemecahan masalah dalam meningkatkan hasil belajar IPS siswa kelas IV SDN 1 Kedungsarimulyo yaitu dengan menerapkan model pembelajaran yang menarik dan inovatif. Salah satu model pembelajaran yang dapat digunakan untuk mengatasi masalah tersebut adalah dengan menerapkan model pembelajaran kooperatif tipe Teams Games Tournament (TGT) pada pembelajaran IPS kelas IV.

Menurut Slavin (2005: 163-165) model pembelajaran kooperatif tipe Teams Games Tournament (TGT) secara umum sama dengan STAD kecuali satu hal. Teams Games Tournament (TGT) menggunakan turnamen akademik. Dimana para siswa berlomba sebagai wakil tim mereka dengan anggota tim lain yang kinerja akademik sebelumnya setara seperti mereka. Model pembelajaran kooperatif tipe Teams Games Tournament (TGT) membuat siswa terlibat aktif dalam kelompok. Paper ini melaporkan peningkatan hasil belajar IPS siswa kelas IV sekolah dasar dengan model pembelajaran kooperatif tipe teams games tournament (TGT).

aspek, yaitu: belajar tertuju kepada apa yang harus dilakukan oleh siswa, mengajar berorientasi pada apa yang harus dilakukan oleh guru sebagai pemberi pelajaran. Kedua aspek ini akan berkolaborasi secara terpadu menjadi suatu kegiatan pada saat 
terjadi interaksi antara guru dengan siswa, serta antara siswa dengan siswa disaat pembelajaran sedang berlangsung (Jihad, 2013: 11).

Arends dalam Trianto (2010: 22) menyatakan, "The tern teaching model refers to a particular approach to instruction that includes its goals, syntax, environment, and management system." Istilah model pengajaran mengarah pada suatu pendekatan pembelajaran tertentu termasuk tujuannya, sintaknya, lingkungannya, dan sistem pengelolaanya.

Huda (2013: 265) mengungkapkan bahwa pembelajaran kooperatif membantu siswa bersikap positif terhadap pembelajaran, bersedia untuk terlibat bersama teman-temannya, dan bekerja sama untuk saling meningkatkan pembelajarannya masing-masing. Siswa akan belajar bagaimana menangani konflik, menghargai pendapat orang lain, bernegosiasi untuk menyelesaikan tugas akademik, dan saling berbagi gagasan dan sumber-sumber.

Slavin (2005: 169) menjelaskan bahwa sebelum melaksanakan TGT siswa terlebih dahulu ditempatkan ke dalam tim heterogen kemudian siswa ditempatkan ke dalam meja turnamen homogen. Kemudian siklus regular dari pembelajaran TGT dapat dilaksanakan sebagai berikut:

(1) Pengajaran, menyampaikan materi
(2) Belajar tim, para siswa mengerjakan lembar kegiatan dalam tim mereka untuk menguasai materi

(3) Turnamen, para siswa memainkan game akademik dalam kemampuan yang homogen, dengan meja turnamen tiga peserta

(4) Rekognisi tim, skor tim dihitung berdasarkan skor turnamen anggota tim, dan tim tersebut akan direkognisi apabila mereka berhasil melampaui kriteria yang telah di tetapkan sebelumnya.

Trianto (2010: 84) menjelaskan aturan (skenario) dalam turnamen, yaitu satu permainan terdiri dari kelompok pembaca, kelompok penantang 1, kelompok penantang 2, dan seterusnya. Kelompok pembaca bertugas mengambil kartu bernomor dan menjawab pertanyaan, kemudian kelompok penantang bertugas menyetujui atau memberi jawaban yang berbeda. Kegiatan ini dilakukan secara bergiliran sampai periode kelas berakhir atau jika soal yang tersedia sudah habis.

Slavin (2005: 174) menjelaskan cara menentukan skor turnamen yaitu dengan cara memeriksa poin poin turnamen yang ada pada lembar skor permainan kemudian pindahkan poin-poin turnamen dari tiap siswa ke lembar 
rangkuman dari timnya masing-masing. mencapai kriteria tertentu dapat diberikan

Kemudian dijumlahkan untuk sertifikat atau ganjaran (award) yang lain.

mendapatkan skor tim, dan tim yang

Tabel 1.1 Menghitung Poin-poin Turnamen untuk 3 Pemain

\begin{tabular}{|c|c|c|c|c|}
\hline Pemain & $\begin{array}{c}\text { Tidak ada } \\
\text { yang seri }\end{array}$ & $\begin{array}{c}\text { Seri nilai } \\
\text { tertinggi }\end{array}$ & $\begin{array}{c}\text { Seri nilai } \\
\text { terendah }\end{array}$ & $\begin{array}{c}\text { Seri 3 } \\
\text { macam }\end{array}$ \\
\hline Peraih skor tertinggi & 60 poin & 50 poin & 60 poin & 40 poin \\
\hline Peraih skor tengah & 40 poin & 50 poin & 30 poin & 40 poin \\
\hline Peraih skor rendah & 20 poin & 20 poin & 30 poin & 40 poin \\
\hline
\end{tabular}

Sumber: Slavin (2005:175)

Tabel 1.2 Kriteria Penghargaan Tim

\begin{tabular}{|c|c|}
\hline Kriteria (Rata-rata tim) & Penghargaan \\
\hline 40 & Tim Baik \\
\hline 45 & Tim Sangat Baik \\
\hline 50 & Tim Super \\
\hline
\end{tabular}

Sumber: Slavin (2005:175)

\section{HASIL BELAJAR}

Dalam penelitian ini menggunakan klasifikasi hasil belajar dari Benyamin Bloom yang secara garis besar dibagi menjadi tiga ranah, yakni ranah kognitif, ranah afektif, dan ranah psikomotorik.

Sudjana (2012: 23) menjelaskan tipe masing-masing ranah sebagai berikut.

(1) Ranah kognitif, berkenaan dengan hasil belajar intelektual dan diklasifikasikan dalam enam tipe hasil belajar antara lain: (a) pengetahuan, (b) pemahaman, (c) aplikasi, (d) analisis, (e) sintesis, (f) evaluasi,
(2) Ranah afektif, ada beberapa jenis kategori ranah afektif sebagai hasil belajar, kategorinya dimulai dari tingkat sederhana sampai yang kompleks antara lain. (a) receiving/attending, (b) responding atau jawaban, (c) valuing atau penilaian, (d) organisasi, (e) internalisasi nilai.

(3) Ranah psikomotoris, hasil belajar psikomotoris tampak dalam bentuk keterampilan (skill) individu. Ada enam tingkatan keterampilan, yakni: (a) gerak refleks, (b) keterampilan pada gerakan-gerakan dasar, (c) 
kemampuan perseptual, (d) kemampuan fisik, (e) gerakangerakan skill, dan (f) kemampuan komunikasi. hasil belajar tersebut sebenarnya tidak berdiri sendiri, tetapi selalu berhubungan satu sama lain.

\section{PEMBELAJARAN IPS}

Suprayogi (2011: 129) menjelaskan bahwa IPS berusaha mengintegrasikan bahan atau materi dari cabang ilmu-ilmu sosial dengan menampilkan permasalahan sosial sehari-hari yang mencakupi hubungan antar orang, hubungan antara orang dengan lingkungan hidupnya, dan hubungan dengan lembaga, antar kelompok dan antar bangsa, hubungan antara manusia dengan benda-benda keperluan hidup.

Menurut Gunawan (2011: 37) pembelajaran IPS bertujuan membentuk warga Negara yang berkemampuan sosial dan yakin akan kehidupannya sendiri di tengah-tengah kekuatan fisik dan sosial, yang pada gilirannya akan menjadi warga Negara yang baik dan bertanggung jawab, sedangkan ilmu sosial bertujuan menciptakan ahli dalam bidang ilmu sosial.

Dalam penelitian ini peneliti memfokuskan peningkatan hasil belajar IPS kelas IV SDN 1 Kedungsarimulyo pada ruang lingkup IPS "Perilaku ekonomi dan kesejahteraan". Dimana dalam Permendiknas nomor 22 Tahun 2006 tentang Standar Isi ruang lingkup tersebut terdapat pada standar kompetensi: 2. Mengenal sumber daya alam, kegiatan ekonomi, dan kemajuan teknologi di lingkungan kabupaten/kota dan provinsi. Kompetensi dasar: 2.1 Mengenal aktivitas ekonomi yang berkaitan dengan sumber daya alam dan potensi lain di daerahnya. Materi ini termasuk dalam ruang lingkup IPS yang keempat, yaitu perilaku ekonomi dan kesejahteraan.

Dari segi kekayaan alam yang tersedia baik potensial maupun latensial, Indonesia termasuk "rich country" atau Negara kaya. Kekayaan tersebut dapat disaksikan pada kekayaan laut, kekayaan tambang dan mineral, luasnya lahan yang subur beserta kekayaan-kekayaan alam lainnya (Soetrisno, 1984: 126).

Lipsey (1990: 4) menjelaskan bahwa sumber daya suatu masyarakat terdiri dari anugrah alam seperti tanah, hutan dan tambang, sumber daya manusia, baik mental maupun fisik, dan alat bantu buatan untuk memproduksi seperti peralatan, mesin dan bangunan.Sumber daya alam tersebut berdampak penting pada aktivitas ekonomi masyakat. Orang menggunakan barang dan jasa untuk memenuhi kebutuhannya. 
KERANGKA BERPIKIR

Peneliti menerapkan model pembelajaran kooperatif tipe Teams Games Tournament (TGT) dalam pembelajaran IPS melalui siklus I dan siklus II. Siklus I dilaksanakan untuk meningkatkan hasil belajar siswa. Sedangkan siklus II dilaksanakan untuk membuktikan keefektifan model pembelajaran kooperatif tipe Teams Games Tournament (TGT) dalam meningkatkan hasil belajar siswa.

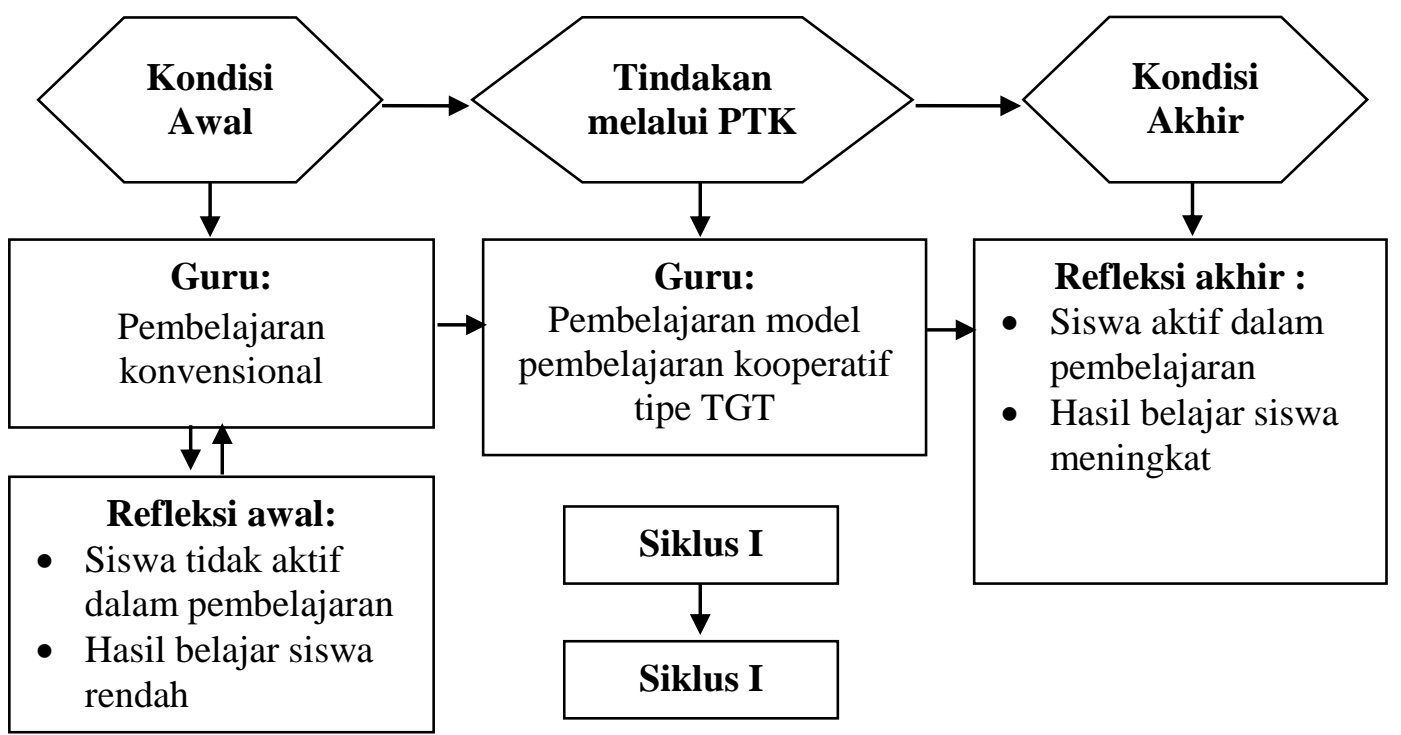

\section{Gambar 1.1 Kerangka Berfikir}

Guru dalam mengajarkan IPS pada siswa kelas IV SDN 1 Kedungsarimulyo masih konvensional dan kurang bervariasi. Guru lebih sering menggunakan metode ceramah yang menempatkan guru sebagai pusat informasi. Hal tersebut menyebabkan siswa kurang aktif dalam proses pembelajaran yang berdampak pada rendahnya hasil belajar IPS siswa.

Berdasarkan masalah tersebut, peneliti berusaha mencari pemecahannya yaitu dengan menerapkan model pembelajaran kooperatif tipe Teams Games Tournament (TGT) untuk meningkatkan hasil belajar siswa. Pembelajaran dengan model pembelajaran kooperatif tipe Teams Games Tournament (TGT) dapat melibatkan aktivitas seluruh siswa dalam belajar dan membuat siswa lebih bersemangat serta dapat menumbuhkan tanggung jawab, kerja sama, persaingan sehat melalui kegiatan diskusi dan turnamen.

$$
\text { Peneliti menerapkan model }
$$
pembelajaran kooperatif tipe Teams Games Tournament (TGT) dalam pembelajaran IPS melalui siklus I dan siklus II. Siklus I dilaksanakan dalam upaya meningkatkan hasil belajar siswa. Sedangkan siklus II dilaksanakan untuk membuktikan keefektifan model pembelajaran kooperatif tipe Teams 
Games Tournament (TGT) dalam meningkatkan hasil belajar siswa.

Penerapan model pembelajaran kooperatif tipe Teams Games Tournament (TGT) ini diharapkan akan dapat meningkatkan hasil belajar siswa pada

\section{METODE PENELITIAN}

\section{LOKASI PENELITIAN}

Penelitian tindakan kelas ini dilaksanakan di SDN 1 Kedungsarimulyo yang beralamat di Desa Kedungsarimulyo Kecamatan Welahan Kabupaten Jepara.

mata pelajaran IPS kelas IV SDN 1 Kedungsarimulyo Welahan Jepara. Kerangka berfikir dalam penelitian ini sebagai berikut.

Penelitian ini dilakukan selama 5 bulan yaitu dimulai dari November 2013 sampai Maret 2014 meliputi perencanaan, pelaksanaan, dan penyusunan laporan PTK.

\section{DESAIN PENELITIAN}

\section{SUBJEK PENELITIAN}

Desain penelitian ini menggunakan model Kemmis dan Mc Taggart.

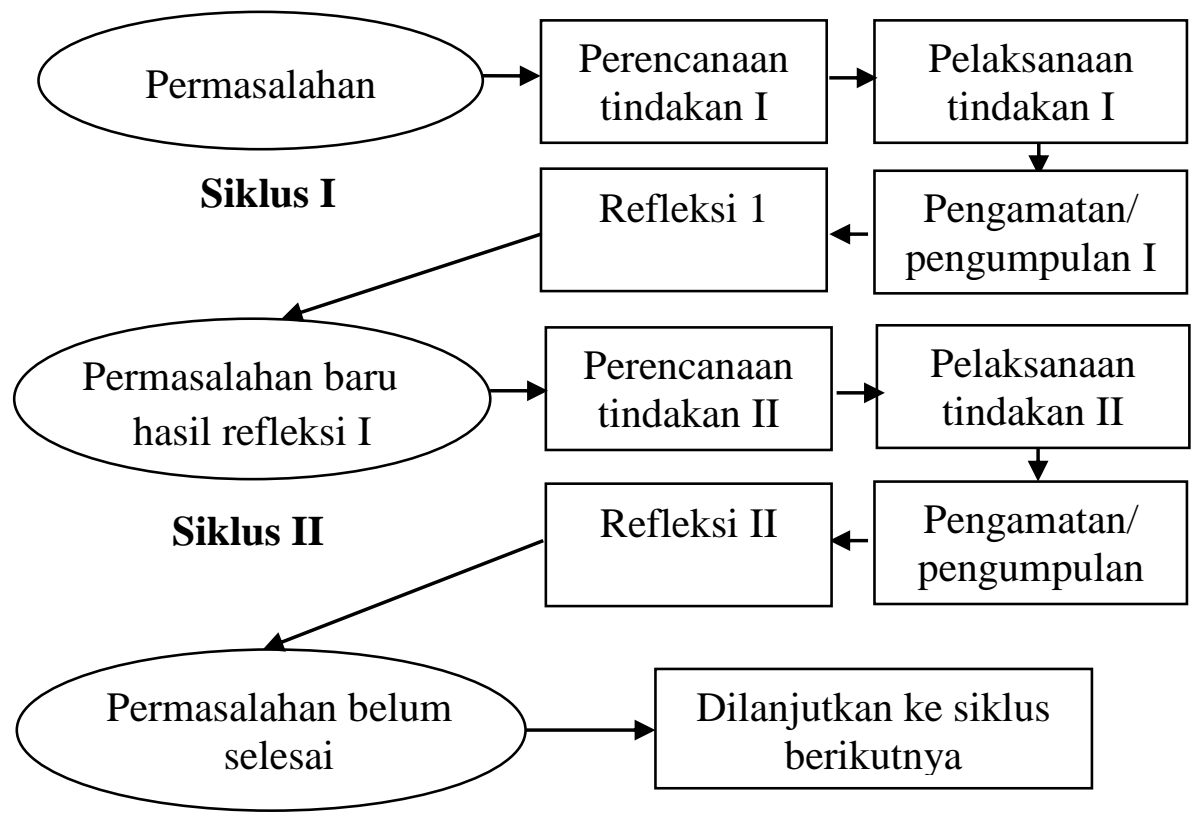

Bagan Desain Penelitian Model Kemmis dan Mc Taggart

(Arikunto, 2011: 74)

\section{METODE PENGUMPULAN DATA}

1. Metode Observasi

Metode observasi digunakan untuk mengumpulkan data berkaitan dengan aktivitas belajar siswa dan keterampilan mengajar guru.

2. Metode Wawancara

Metode wawancara digunakan pada saat pra penelitian yaitu untuk 
memperoleh informasi berkaitan dengan permasalahan pembelajaran IPS di kelas IV. Wawancara dilakukan terhadap guru kelas IV.

3. Metode Tes

Metode tes digunakan untuk mengumpulkan data kuantitatif dari penelitan. Tes dilakukan dua kali,

\section{TEKNIK ANALISIS DATA}

1. Analisis Data Kuantitatif

Teknik analisis data kuantitatif digunakan untuk menganalisis data dari tes. Data kuantitatif berupa hasil belajar siswa yang mengukur kemampuan kognitif

$$
\text { Skor }=\frac{B}{N} \times 100
$$

Keterangan:

$\mathrm{B}=$ banyaknya butir yang dijawab benar

$\mathrm{N}=$ banyaknya butir soal

Hasil perhitungan skor kemudian dikonfirmasikan dengan tabel kriteria ketuntasan belajar siswa yang

\section{Tabel 1.3 Kriteria Ketuntasan Belajar IPS Kelas IV}

\begin{tabular}{|c|c|}
\hline Kriteria ketuntasan & Kualifikasi \\
\hline$\geq 63$ & Tuntas \\
\hline$<63$ & Tidak tuntas \\
\hline
\end{tabular}

Sumber : SDN 1 Kedungsarimulyo Welahan Jepara

Apabila perolehan nilai hasil tes pembelajaran IPS kelas IV di SDN 1 siswa $\geq 63$ maka siswa dianggap tuntas, Kedungsarimulyo adalah 63. Untuk jika tingkat ketuntasan < 63 maka siswa menghitung persentase ketuntasan belajar dianggap belum tuntas karena KKM pada klasikal adalah sebagai berikut.

$$
\mathrm{P}=\sum \text { siswa yang tuntas belajar }: \text { S siswa } \times 100 \%
$$


Hasil dari prosentase kemudian dalam \% dengan menggunakan tabel 1.4. dianalisis untuk mendapatkan kategori

Tabel 1.4 Kriteria Tingkat Keberhasilan Belajar Siswa

\begin{tabular}{|c|c|}
\hline Prosentase & Kriteria \\
\hline$>80 \%$ & Sangat Tinggi \\
\hline $60-79 \%$ & Tinggi \\
\hline $40-59 \%$ & Sedang \\
\hline $20-39 \%$ & Rendah \\
\hline$<25 \%$ & Sangat Rendah \\
\hline
\end{tabular}

Sumber : Aqib (2011 : 41)

2. Analisis Data Kualitatif belajar siswa dan pengelolaan

Analisis data kualitatif menggunakan pembelajaran guru. rating- scale untuk mengamati aktibitas

Tabel 1.5 Rating-Scale Lembar Pengamatan

\begin{tabular}{|c|c|}
\hline Skor & Keterangan Penilaian \\
\hline Skor 1 & Dilakukan sangat tidak baik \\
\hline Skor 2 & Dilakukan cukup baik \\
\hline Skor 3 & Dilakukan dengan baik \\
\hline Skor 4 & Dilakukan sangat baik \\
\hline
\end{tabular}

Sumber : Sugiono (2012: 141)

Berikut rumus menghitung skor ratarata perolehan hasil observasi pengelolaan pembelajaran guru dan aktivitas belajar siswa.

Skor
Total Skor

Kriteria penilaian pengelolaan pembelajaran guru dengan model pembelajaran kooperatif tipe Times Games Tournament (TGT) ditentukan dengan interval sebagai berikut.

$0,00<$ skor rata-rata $\leq 1,00$ : pengelolaan pembelajaran tidak baik
$1,00<$ skor rata-rata $\leq 2,00$ : pengelolaan pembelajaran cukup baik

$2,00<$ skor rata-rata $\leq 3,00:$ pengelolaan pembelajaran baik

$3,00<$ skor rata-rata $\leq 4,00$ : pengelolaan pembelajaran sangat baik

Kriteria penilaian aktivitas belajar siswa ditentukan dengan interval sebagai berikut.

1 <skor rata-rata $\leq 1,75$ : aktivitas belajar siswa tidak baik 
$1,75<$ skor rata-rata $\leq 2,5:$ aktivitas belajar siswa cukup baik

$2,5<$ skor rata-rata $\leq 3,25$ : aktivitas belajar siswa baik

\section{INDIKATOR KEBERHASILAN}

1. Nilai rata-rata kelas mencapai nilai $\mathrm{KKM}$ atau $\geq 63$ dengan ketuntasan belajar klasikal minimal 60-79\% dengan kriteria tinggi.
$3,25<$ skor rata-rata $\leq 4$ : aktivitas belajar siswa sangat baik
2. Aktivitas belajar siswa minimal baik dengan interval skor 2,5 <skor ratarata $\leq 3,25$.

3. Pengelolaan pembelajaran guru minimal baik dengan skor rata-rata $2,00<$ skor rata-rata $\leq 3,00$.

dengan ketuntasan belajar klasikal 69,4\%. Nilai minimal 53,3 dan nilai maksimal 100. Sedangkan pada siklus II hasil belajar IPS siswa menunjukkan peningkatan dengan nilai rata-rata 73,9 dan ketuntasan klasikal 75\%. Nilai minimal siswa 53,3 dan nilai maksimal 100. Secara ringkas, peningkatan rata-rata nilai hasil belajar IPS siswa disajikan pada gambar 1 dan peningkatan persentase ketuntasan klasikal pada gambar 2 berikut ini.

\section{Peningkatan Hasil Belajar IPS Siswa}

\section{Aspek Kognitif}

Telah terjadi peningkatan hasil belajar aspek kognitif dari pra siklus, siklus I, sampai siklus II. Pada pra siklus menunjukkan rata-rata nilai hasil belajar IPS 61,4 dengan ketuntasan belajar klasikal 52,7\%. Nilai minimal 20 dan nilai maksimal 90. Siklus I menunjukkan ratarata nilai hasil belajar sebesar 71,48

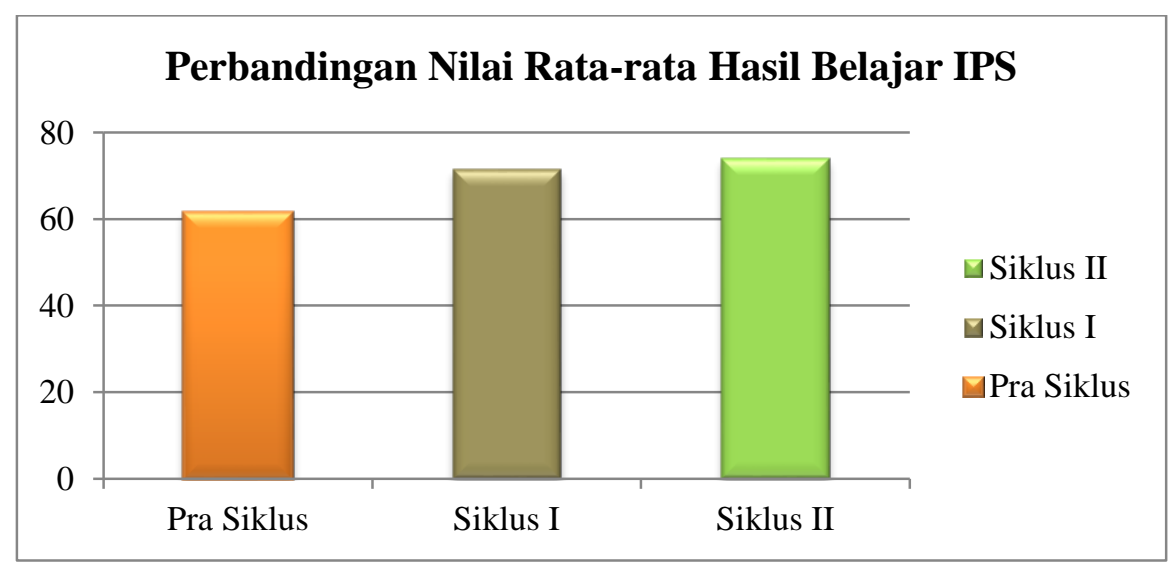

Gambar 1 Diagram Batang Perbandingan Nilai Rata-rata Hasil Belajar IPS Siswa Pra siklus, Siklus I, dan Siklus II 


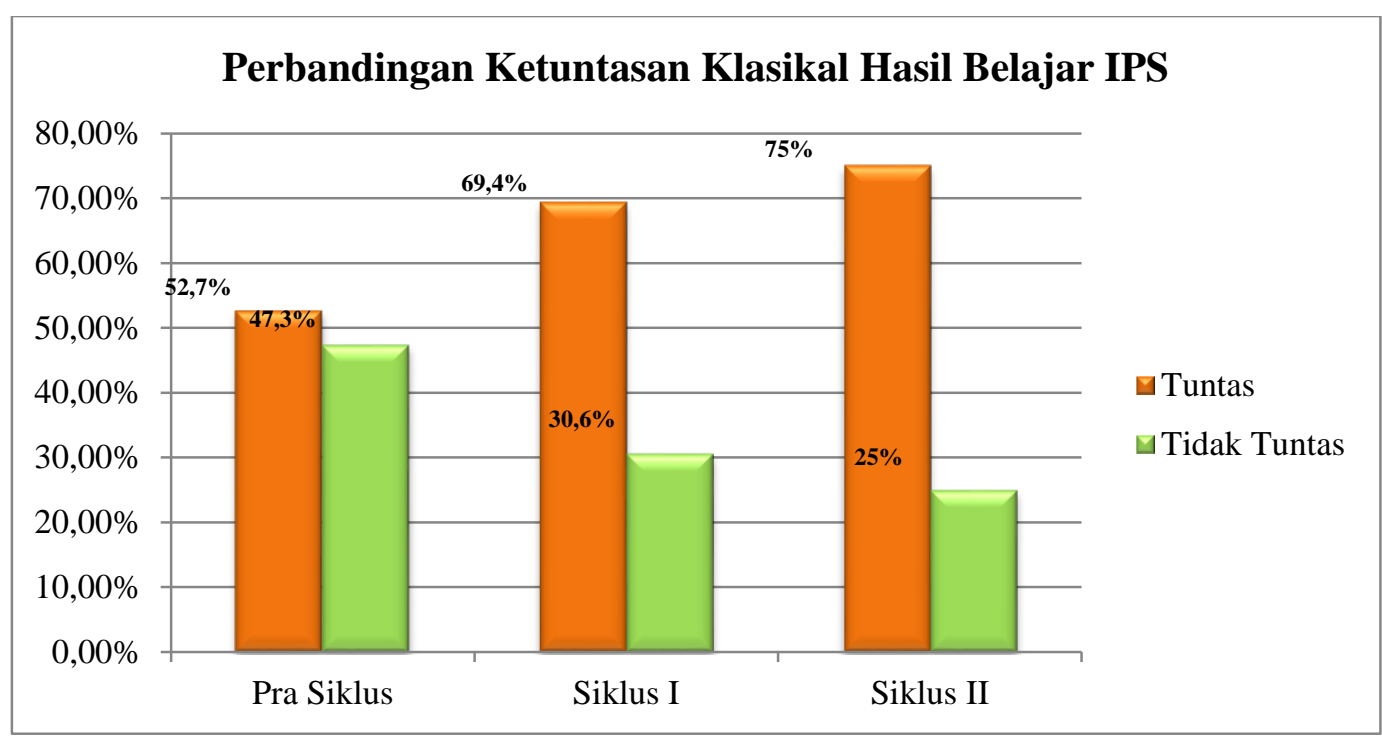

Gambar 2 Diagram Batang Perbandingan ketuntasan klasikal Hasil Belajar IPS Siswa Pra siklus, Siklus I, dan Siklus II

Menurut Hamalik (2012: 75) penilaian hasil pembelajaran merupakan tujuan penting dalam rangka sistem pembelajaran. Pengajaran dianggap berhasil jika siswa mencapai tujuan yang telah ditentukan. Ketercapaian tujuan oleh siswa menjadi indikator keberhasilan sistem pembelajaran.

\section{Aktivitas Belajar Siswa dalam Pembelajaran IPS}

Telah terjadi peningkatan aktivitas belajar IPS, pada siklus I memperoleh rata- rata 2,46 dengan kategori penilaian cukup baik, pada siklus I aktivitas belajar siswa belum mencapai indikator keberhasilan yaitu minimal baik dengan interval skor $2,5<$ skor rata-rata $\leq 3,25$. Kemudian pada siklus II meningkat menjadi 2,87 dengan kategori baik dan sudah mencapai target yang diinginkan. Secara ringkas skor ratarata aktivitas belajar siswa siklus I dan II disajikan dalam bentuk diagram batang seperti gambar 3 berikut ini.

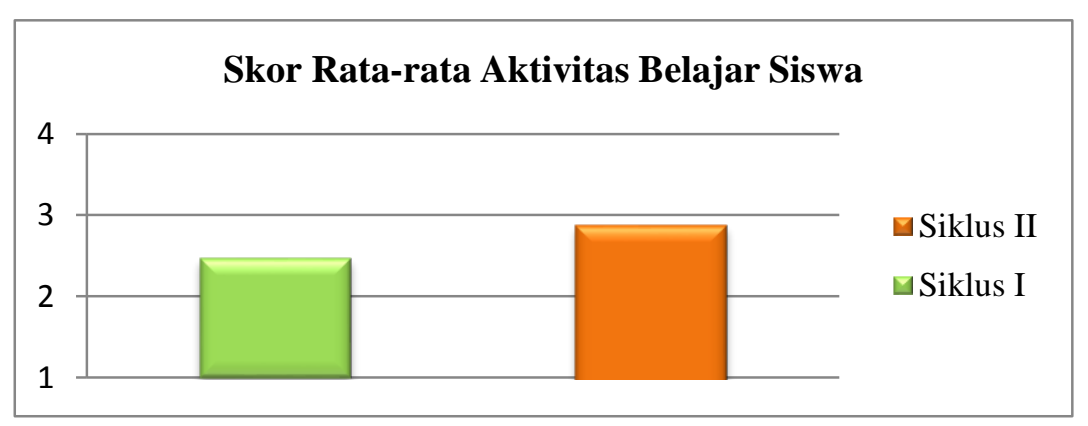

Gambar 5.3 Diagram Batang Perbandingan Skor Rata-rata Aktivitas Belajar Siswa Siklus I dan Siklus II 
Berdasarkan uraian diatas dapat disimpulkan bahwa ada peningkatan aktivitas belajar siswa kelas IV SDN 1 Kedungsarimulyo melalui penerapan model pembeajaran kooperatif tipe Teams Games Tournament (TGT).

\section{Pengelolaan Pembelajaran Guru}

Telah terjadi peningkatan pengelolaan pembelajaran guru. Pada siklus I pengelolaan pembelajaran guru memperoleh skor rata-rata 2,36 dengan kriteria baik. Pada siklus II, pengelolaan pembelajaran guru skor rata-ratanya meningkat menjadi 3,08, dengan kriteria sangat baik. Hasil pengamatan pengelolaan pembelajaran guru menggunkaan model pembelajaran kooperatif tipe Teams Games Tournament (TGT) pada siklus I dan siklus II disajikan dalam gambar 4 berikut ini.

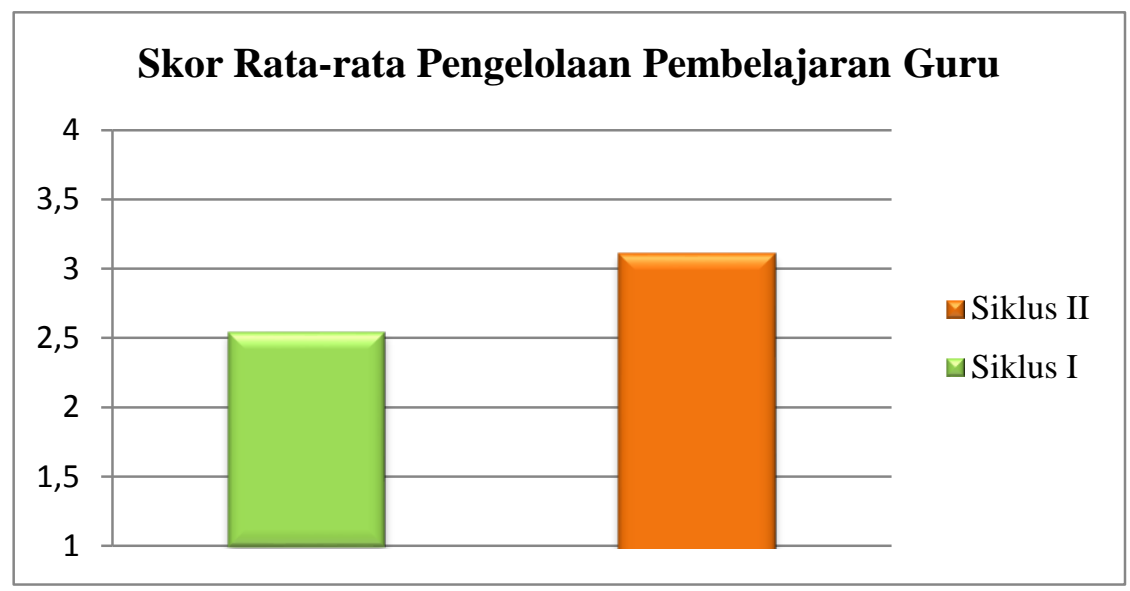

\section{Gambar 4 Diagram Batang Skor Rata-rata Pengelolaan Pembelajaran Guru Siklus I}

dan Siklus II

Pengelolaan pembelajaran guru dengan model pembelajaran kooperatif tipe Teams Games Tournament (TGT) diperoleh kriteria sangat baik sehingga dapat meningkatkan hasil belajar dan aktivitas belajar siswa kelas IV SDN 1 Kedungsarimulyo Welahan Jepara. Trianto (2010: 17) menjelaskan bahwa cara mengajar guru yang baik merupakan kunci dan prasyarat bagi siswa untuk dapat belajar dengan baik. Salah satu tolok ukur bahwa siswa belajar dengan baik ialah jika siswa itu dapat mempelajari apa yang seharusnya dipelajari, sehingga indikator hasil belajar yang diinginkan dapat dicapai oleh siswa.

\section{PEMBAHASAN}

Kelemahan penerapan model pembelajaran kooperatif tipe Teams Games Tournament (TGT) pada penelitian ini yaitu (1) membutuhkan pengelolaan pembelajaran yang baik; (2) membutuhkan persiapan, sarana, dan prasarana yang 
memadai antara lain kartu soal, kartu jawaban, nomor meja turnamen, dan lembar skor turnamen; (3) kelas cenderung ramai ketika penempatan siswa dari kelompok belajar ke meja turnamen; serta (4) siswa yang kurang aktif dalam turnamen dapat mempengaruhi perolehan poin kelompok.

Kelebihan dalam penerapan model pembelajaran kooperatif tipe Teams Games Tournament (TGT) yaitu: (1) siswa menjadi semangat dalam belajar; (2) dapat mengembangkan sikap kerjasama, tanggung jawab, serta sikap persaingan yang baik antar siswa; (3) siswa memperoleh pengetahuan tidak hanya dari guru saja, tetapi melalui konstruksi yang dilakukan sendiri oleh siswa; (4) keterlibatan siswa dalam pembelajaran tinggi; (5) dapat meningkatkan hasil belajar dan aktivitas belajar siswa; serta (6) dapat membentuk guru menjadi professional karena dalam penerapan model pembelajaran kooperatif tipe Teams Games Tournament (TGT) membutuhkan pemikiran yang mendalam mulai dari persiapan, sarana dan prasarana, teknis pelaksanaan turnamen, pemberian penghargaan, serta evaluasi.

\section{PENUTUP}

\section{SIMPULAN}

\begin{tabular}{rrr} 
Telah & berhasil & \multicolumn{2}{c}{ dilaksanakan } \\
penelitian & tindakan kelas untuk
\end{tabular}

meningkatkan hasil belajar IPS siswa kelas IV SDN 1 Kedungsarimulyo tahun pelajaran 2013/2014 menggunakan model pembelajaran kooperatif tipe Teams Games Tournament (TGT). Hal ini dibuktikan dengan tercapainya indikator keberhasilan. Peningkatan hasil belajar ranah kognitif dapat dilihat dari ketuntasan klasikal siswa pra siklus sebesar 52,7\% dengan rata-rata 61,4, meningkat pada siklus I menjadi $69,4 \%$ dengan rata-rata 71,48, dan pada siklus II meningkat menjadi $75 \%$ dengan rata-rata 73,9 . Peningkatan hasil belajar aspek afektif dan psikomotor dilihat dari peningkatan aktivitas belajar siswa pada siklus I ke siklus II yaitu dari skor rata-rata 2,46 menjadi 2,87 dengan kriteria cukup baik menjadi baik. Pengelolaan pembelajaran guru pada siklus I ke siklus II meningkat yaitu dari skor rata-rata 2,36 menjadi 3,08 dengan kriteria baik menjadi sangat baik. Model pembelajaran kooperatif tipe Teams Games Tournament (TGT) dapat dijadikan alternatif untuk meningkatkan hasil belajar IPS siswa.

\section{SARAN}

\section{Bagi Siswa}

Hendaknya siswa bisa lebih bersemangat dan tertib dalam mengikuti pembelajaran IPS menggunakan model pembelajaran kooperatif tipe Teams Games Tournament (TGT). 


\section{Bagi Guru}

(1) Model pembelajaran kooperatif tipe Teams Games Tournament (TGT) dapat dijadikan salah satu alternatif yang dapat digunakan untuk meningkatkan hasil belajar IPS siswa.

(2) Dalam menerapkan model pembelajaran kooperatif tipe Teams Games Tournament (TGT) guru harus memahami skema pembagian kelompok belajar secara heterogen serta pembagian meja turnamen secara homogen.

(3) Dalam menerapkan model pembelajaran kooperatif tipe Teams
Games Tournament (TGT) guru harus mempunyai persiapan yang matang seperti mempersiapkan LKS, kartu soal, kartu jawaban, serta lembar penilaian di meja turnamen.

\section{Ucapan Terima Kasih}

Penulis mengucapkan terima kasih kepada Kepala Sekolah SDN 1 Kedungsarimulyo Welahan Jepara yang telah memberika izin penelitian. Penulis juga mengucapkan terima kasih kepada seluruh warga SDN 1 Kedungsarimulyo Welahan Jepara atas dukungannya pada penelitian ini.

\section{DAFTAR PUSTAKA}

Aqib, Zaenal. 2011. Penelitian Tindakan Kelas Untuk Guru SD. Bandung: Yrama Widya.

Arikunto, Suharsimi. 2011. Penelitian Tindakan Kelas. Jakarta: Bumi Aksara.

Hamalik, Oemar. 2012. Kurikulum dan Pembelajaran. Jakarta: Bumi Aksara.

Jihad, Asep dan Abdul Haris. 2013. Evaluasi Pembelajaran. Yogyakarta: Multi Persindo.

Sudjana, Nana. 2012. Penilaian Hasil Proses Belajar Mengajar. Bandung: PT Remaja Rosdakarya.

Sugiono. 2012. Metode Penelitian Pendidikan Pendekatan Kualitatif, Kuantitatif, dan R\&D. Bandung: Alfabeta.

Slavin, Robet E. 2005. Cooperative Learning: Theory, Research and Practice. Terjemahan Narulita Yusron. Bandung: Nusa Media.

Trianto. 2010. Mendesain Model Pembelajaran Inovatif-Progresif. Jakarta: Kencana. 